\title{
Functions of Art Education in Universities from the Perspective of Social Development
}

\author{
Yuanhong Bi \\ The Center for Arts Education of Faculty of Humanities and \\ Social Sciences \\ Dalian University of Technology \\ Dalian, China 116024
}

\author{
Zhen Zhang \\ Faculty of Music \\ Dalian University \\ Dalian, China 116024
}

\begin{abstract}
Art education in universities not only plays an important role in the personal growth of undergraduates, but also plays a unique role in the development and progress of the society. Analyzing the function of art education in colleges and universities from the multiple perspectives of the development of social culture, economy, and politics has a certain role in extending the concept of art education in ordinary universities, expanding the teaching content of art education, and innovating art curriculum design in colleges and universities.
\end{abstract}

Keywords-artistic education function; cultural system; economic system; political system

\section{INTRODUCTION}

Social development is the process in which culture, economy, politics of society and social groups move forward together. It is a process of self-negation and abandonment. Its fundamental purpose is to promote social development toward a higher and more superior direction. Therefore, social progress is the goal and aspiration of social development. The art education of ordinary colleges and universities realizes its value of promoting social progress depending on providing various talents needed by the society.

\section{A PERSPECTIVE OF THE SOCIO-CULTURAL SySTEM}

In the social system, art, as a unique cultural phenomenon, builds human social ideology together with philosophy, science, morality, and religion. Looking at the living environment of human, art remolds and beautifies the world in the form of solid-state cultures such as architecture and sculpture. It fills people's spiritual life with communication mode of cultural activities and engages and influences the progress and perfection of human ideology in the form of spiritual or interior cultural creations. Therefore, the esthetician М.С.Каган believes that the functional structure of art is adapted to the functional structure of human activities and exerts four functions: communication methods, value orientation methods, cognitive tools, and practices and spiritual tools for transforming the objective world [1]. Art education of ordinary colleges plays an important role in the entire social cultural system.

\section{A. Landscaping of Social Cultural Environment}

For the survival and development of themselves, mankind has carried out a great deal of transformation and construction of the natural environment, and has given the natural environment a deep imprint of the human will. In the history of mankind, most of countless artistic treasures left in nature record the footprint of human civilization. Archeological miracles such as the Egyptian pyramids, the Roman amphitheatre, the Arc de Triomphe and the Eiffel Tower, and the Great Wall of China, as well as sculptures of the Statue of Liberty, grotto sculptures, and Leshan Giant Buddha all show the world cultural powers gathering by human wisdom. These humanized natural landscapes constitute the field of spiritual culture of a group or a country. They constantly promote the awareness of the ethnic groups on their own culture, sustain the cultural identity among generations of ethnic groups, and maintain social cohesion. However, human development footprints do not all show artistic beauty. Some public facilities in cities or regions do not take into account the aesthetic value. There are many examples of this, which is naturally a mistake in education.

The social cultural environment has been given an extensive social meaning in the contemporary era. Small cultural landscapes converge into large humanistic environments and form the value characteristics of fixed ethnic cultural systems. It cannot be achieved only by individual intelligence of artists or architects to create a cultural landscape that can represent the cultural awareness of groups and rich in artistic beauty. It's the result of collective behavior that a cultural landscape representing ethnic cultural characteristics from design to completion. These creators cover a various industries. They should possess a high degree of cultural awareness, cultural awareness, and high-level cultural qualities. In the meanwhile, they also should have abundant artistic aesthetic awareness and artistic creativity, which require the cultivation and excavation of art education.

University artistic education has the function of research. First, it can objectively evaluate the value of all arts and cultures that exist in the social living environment, and can summarize and refine methods and techniques for embedding excellent artistic and cultural elements into the social life environment. Second, art education in universities 
cultivates professional art talents with superb artistic creativity to help them integrate the rich emotions of people into the practice of transforming natural landscapes, enhance their humanistic feelings of protecting the natural environment as well as ideals and beliefs in giving the natural environment an artistic atmosphere. Finally, it can achieve the goal of beautifying the natural environment and building a cultural and ecological environment by providing talents.

\section{B. Harmonization of Social Relations}

The equal exchanges and interactions between human beings constitute a harmonious social and cultural environment, forming a consensus and shared culture with each other, thereby promoting the stability and development of the entire social system. The cultural system is an important carrier for maintaining the interaction and interaction. In the human interaction, art has become the most popular communication tool for people and has penetrated into every corner of social and cultural activities. In the opening ceremony of the Beijing Olympics, tens of thousands of actors demonstrated to the world the artistic ideas of harmony between man and nature contained in the Chinese civilization, and used the art to maintain the national aesthetic recognition and cultural equal exchanges of various countries and peoples.

Art education plays an active role in these artistic and cultural exchanges and promotes the harmony and stability of social relations. It mainly manifests in three aspects:

1) Maintenance of National Moral Consciousness: In the modern era, globalization has become an irreversible historical process. Therefore, the solution to cultural security issues has gradually become a severe test that all countries and nations must actively respond to. The invasion of a strong culture has affected the ideological values of the ethnic groups' psychological habits, emotions, and wills, resulting in a huge impact on the "ethnic elements" of traditional culture and gradually diminishing. Under such circumstances, art education plays a role in spreading and maintaining national moral awareness because "great art can provide people insights similar to religion, and art education makes it possible to obtain such insights. "[2] Artistic culture of a nation has precipitated the knowledge of perceptual quality in the nation's history and culture, and contained rich national cultural spirit and emotions, which express the human's good ideals beyond reality and their belief in trueness and perfection. The moral guidelines that sustain the long history of ethnic culture is the foundation for a nation to stand in a multicultural forest.

2) Convergence of National Emotions: Ancient education in China has paid great attention to the use of art to agglomerate the group emotion. Mr. Li Zehou said: "The music" is to establish the internal human nature through the cultivation of temperament and shaping of emotions, and to achieve the harmonious order of maintaining the society coherently with 'rites'. "[3] It can be seen that art can stimulate the individual's emotional identity with the society in which he lives. In the process of human socialization, art education enhances the identity of individuals to their ethnic art culture and values, and establishes people's national emotions. In this way, people can use artistic communication methods in social activities flexibly to promote the harmony and stability of social development.

3) Filtration and Absorption of Foreign Art Culture: The rapid development of globalization and digital information technology has made cultural exchanges among various nation-states, groups, and persons and persons more convenient. Many foreign art cultures are directly embedded in popular culture, and there is no lack of values or national wills inconsistent with traditional Chinese cultural heritage. The erosion of these foreign art cultures on mass culture consumption have fierce conflicts with the national will, which is not conducive to "the extension of the national cultural tradition"'[4]. Art education can critically inherit the excellent art culture of the nation, and can also objectively understand, absorb, and integrate foreign art cultures, and act as a "filter" for social arts and cultural activities.

\section{PERSPECTIVE OF THE SOCIO-ECONOMIC SYSTEM}

Art both has the dual attributes of social utilitarianism and surreal utilitarian aesthetics, which enable it to develop and boom without dependence on economic base. The traditional art education is not constrained by the economic system. It has always maintained its characteristics such as independence and public benefit. It is committed to stimulating the aesthetic potential of human beings and has exerted an important influence on the field of social ideology by taking this. In the 1920 s, with the booming of arts and cultural industries, the educational function of art education has moved toward pragmatism. The relationship between art education and economic system has undergone a fundamental change, and its influence has begun to infiltrate from cultural system to economic system little by little.

In 1944, Horkheimer put forward the concept of "cultural industry" for the first time in Art and "Popular Culture". He believed that "cultural products are mass-produced by means of normalization and standardization through technological means, and delivered to consumers through the mass media. Purposive aimlessness makes the cultural industry have the characteristics of consumption, commerce, and entertainment. "[5] It clarified that artistic product, as a category of cultural products, can bring greater economic benefits only through a virtuous circle of production-distribution-consumption. College art education plays an important role in the cycle.

\section{A. The Accumulation of Human Capital in the Arts Field}

In the 1960s economists Theodore William Schultz and Becker and others constructed the theory of human capital in the field of economic growth. They believe that human capital is an important factor of production and a decisive factor in social progress and economic growth. The formation of human capital depends on education. This theory has greatly enriched the connotation of higher 
education functions, and proved that the impact of higher education on the economic system lies in the fact that it provides a systematic way of thinking and professional skills for human resources, making the social division of labor is getting thinner and thinner, the speed of capital accumulation has accelerated and the number of specialized employees has steadily increased. From the perspective of human capital theory, art education in university provides a large amount of human resources for the arts and culture industry, which brings huge economic benefits.

\section{B. The Accumulation of Artistic Creation Elements}

The life of art and culture industry lies in the art products. Maintaining the originality of the art and cultural product contents is the core element supporting the sustainable development of the industry. Judging from the product content of the artistic and cultural industry, it mainly belongs to the category of artistic knowledge that requires high creativity. At the same time, as a cultural product that satisfies people's spiritual consumption, its content also needs to maintain a certain degree of fashion. In general, the art and cultural production needed in the market must be able to create high-quality artistic products, but also to meet popular tastes.

Depending on the teaching of advanced knowledge, university art education cultivates people's high-level artistic taste, trains their aesthetic creativity, enhances the aesthetic standards of their artistic production activities, lays a solid cultural foundation for their social creation activities, and provides rich creative element for artistic production.

\section{PERSPECTIVE OF SOCIAL POLITICAL SYSTEM}

In a broad sense, politics is the operational process of power; in a narrow sense, it is the efforts of some groups expanding their beliefs or welfare to other groups. [6] The political system builds a stable social system and code of conduct by spreading political values of "consensus" in social ideology.

Art is an important part of social ideology and has transcendental qualities. It uses "its own self-discipline and complex operational logic" [7] to expose and critique social reality, demonstrate the social picture of freedom and ideal as well as exert its own influence on the political system. Learners can obtain the political ideology and aesthetic evaluation of artists in the study of artistic work. This kind of aesthetic evaluation reflects and criticizes social reality under certain conditions, and diagnoses and treats social diseases, [8] thus awakening learners' thoughts and forming a good political attitude.

A stable political system creates a good social environment for the development of college art education. Conversely, high-quality art education in universities also promotes the dissemination and innovation of social art culture, enhances cultural strength of the country, and reflects the pros and cons of national political ecology.

\section{A. Aesthetic Evaluation and Orientation of Political Ideals}

As early as in the pre-Qin period, Confucianism attached great importance to the political role of art culture. They believed that awakening people's recognition of the cultural tradition of "rites and music" would make society stable and orderly and form a consistent political ideal. From the very beginning, Confucius has always strongly advocated using artistic education to improve the moral virtues of the political elite. The idea of "Good manners, then gentlemen" expressed his good ideals to achieve a unity of "beauty" and "goodness" on the leader. Looking at the history of mankind, we can see that the morality and culture of a political leader determines the means of governance and political affinity and directly affects the political stability of the era. And good art education also makes political leaders more charismatic, which has been proved by the political leaders such as Churchill and Putin.

Art education in university not only provides talents for the dissemination and propaganda to achieve the political function of art, but also plays the role of researcher, think tank, and interpreter. It evaluates contemporary political issues by the value judgment criterion of "appreciating beauty" and "advocating moral". It influences people's political ideals by the rich emotions of humankind and spread them widely, thus playing a guiding role in the formation and development of ideology in the political system, and also serving as a warning to various negative factors hindering political stability.

\section{B. Leading and Cohesion of Public Political Orientation}

As a means of people's communication, art can fulfill the function of social organization - making people united for the noble social aesthetic ideals in the struggle of social forces. [1] It can convey ideas, influence thinking, promote beliefs, and participate in interpersonal communication and political thought control in the form of cultural symbols. In the contemporary era, the high development of mass communication has brought art and the public closer. The popular tendency of art is becoming clearer. While the aesthetic purport of art is threatened, the social cultural functions of art, including its political functions, are being strengthened.

Art education in university, bearing the profound knowledge of art, produces new knowledge and new ideas of art. It attracts a large number of teachers and researchers to engage in teaching and research. They make the straightaway academic expression from the perspective of research and a simple explanation of the political value orientation in excellent art culture. It solves problems for the public through the public cultural communication, help cultivate the public's political thoughts, guide citizens to form healthy and positive values, and make them unified under the overall interest of the development of the state and the nation. This is the special needs of the political system of contemporary civil society to the function of university art education. 


\section{CONCLUSION}

Therefore, from the perspective of social development, art education in university has cultural functions, economic functions, and political functions. It creates a social and cultural environment by transporting talents, strengthens the harmonious relationship between people and people, promotes the development of art and culture, provides elements of artistic creation, and guides social and political atmosphere and leads public political orientation.

\section{REFERENCES}

[1] [Estonia]Storovitch.Translated by Ling Jiyao. The Functions of Artistic Activities [M]. Xuelin Publishing House,2008.3,10,68,74. ] [爱沙尼亚]斯托洛维奇. 凌继尧译. 艺术活动的功能[M]. 学林出版 社, 2008.3， 10, 68, 74 .

[2] Bennett Reimer.A Philosophy of Music Education,2nd ed.[M].N.J:Prentice Hall,1989:277.

[3] Li Zehou. Huaxia Aesthetics [M]. Guangxi Normal University Press, January 2001, first edition. 29. 李泽厚.华夏美学[M].广西师范大学 出版社, 2001 年 1 月第 1 版.29.

[4] Wang Liesheng, etc. National Public Cultural Service System Theory [M]. Beijing: Culture and Art Publishing House, 2009.83. 王列生等. 国家公共文化服务体系论[M]. 北京: 文化艺术出版社, 2009.83.

[5] Horkheimer et al. Translated by Hong Peiyuet al. Enlightenment Dialectics [M]. Chongqing: Chongqing Publishing House, 1990.148167. 霍克海默等.洪佩郁等译.启蒙辩证法[M]. 重庆: 重庆出版 社, 1990.148-167.

[6] Zheng Yanxiang. Educational Functions and Efficiency [M]. Wide Angle Press Co., Ltd., 1995. 23. 郑燕祥. 教育的功能与效能[M].广 角镜出版社有限公司,1995 版.23.

[7] Gao Xuanyang. Bourdieu's Social Theory [M]. Shanghai: Tongji University Press, 2006.82. 高宣扬.布迪厄的社会理论[M].上海：同 济大学出版社, 2006.82 .

[8] Huang Wenjie. The Aesthetic Form: in the Context of Alienation and Authenticity [J]. Social Sciences in Nanjing. 2006, Vol. 10, pp. 42-45. 黄文杰.审美形式: 在异化与本真之际[J].南京社会科学.2006 年第 十期.42-45. 